\title{
Does municipal ownership affect audit fees?
}

\author{
Linus Axén ${ }^{1} \cdot$ Torbjörn Tagesson $^{1} \cdot$ Denis Shcherbinin ${ }^{1} \cdot$ Azra Custovic $^{1}$. \\ Anna Ojdanic ${ }^{1}$
}

Published online: 11 October 2018

(C) The Author(s) 2018

\begin{abstract}
This study analyses whether municipal ownership affects and determines audit fees. Our model of the determinants of audit fees was tested on data from 249 Swedish municipal and 240 private corporations within the real estate industry, thus extending the study of audit fees to hybrid organizations. The statistical analysis was followed up with interviews of five partners from five different audit firms. The result of the study shows that municipal corporations are paying significantly lower audit fees than equivalent private corporations. This finding is primarily explained by lower perceived business risk and by the fact that municipalities are able to push prices by coordinating procurements of audit services.
\end{abstract}

Keywords Audit fees · Business risk · Hybrid organizations · Municipal ownership · Reputation risk

\section{Introduction}

A large number of studies explain the determination of audit fees in public corporations (e.g. Simunic 1980; Holm and Thinggaard 2014; André et al. 2016), private corporations (e.g. Willekens and Achmadi 2003; Hope and Langli 2010; Sundgren and Svanström 2013) and public sector organizations (e.g., Baber 1983; Baber et al. 1987; Johnsen et al. 2004; Basioudis and Ellwood 2005a, b; Collin et al. 2017). However, in this study, we focus on a particular category of companies, namely municipal corporations. During the last decades, local governments have gradually reduced direct forms of management in favour of various forms of corporatisation, public-private partnership and contracting out (Agrento et al. 2010; Tagesson and Grossi 2012).

Torbjörn Tagesson

Torbjorn.Tagesson@liu.se

1 Department of Management and Engineering, Business Administration, Linköping University, 58183 Linköping, Sweden 
According to Collin et al. (2009), these corporations "are located in a twilight zone, being both private in one sense, acting according to the legislation of joint stock companies, and public in another sense, oriented towards fulfilling the needs of the municipal citizenry". Thus, municipal corporations are examples of hybrid organizations with a combination of public and private characteristics and objectives and they are subjected to demands from both public and private sectors (Thomasson 2009a), operating at the intersection of the market and the public sector (Grossi and Thomasson 2015). Despite a period of increased hybridity and interest in hybrid organizations, the phenomenon is still not very well researched and the literature remains sparsely spread across many academic disciplines (Billis 2010) this also applies to the audit fee research area (Hay 2013).

In line with previous research, we build on Simunic (1980) considering the audited organization as well as the audit market, this will be discussed in more detail in the methodology section. The aim of this study is to examine whether municipal ownership is a factor that affects and determines audit fees.

The remainder of the paper is structured as follows: in the next section we give a brief description of the institutional setting for municipally-owned corporations. The theory section follows with the derivation of hypotheses. The next sections describe the empirical method and the analysis. The article ends with discussion, conclusions and suggestions for further research.

\section{Theory and hypothesis development}

The demands facing hybrid organizations are often contradictory, which generates ambiguity (Kickert 2001). By having a multidimensional goal structure, hybrid organizations often need to handle conflicting demands related to, for example organizational effectiveness, profitability or different societal goals (Lindqvist 2013; Grossi et al. 2017). In addition to multidimensional goals, auditors as well as managers also have to consider and balance the demands from different, and sometimes heterogeneous, stakeholders (e.g. Jansson 2005; Calabró et al. 2013). That the corporations are part of a political context could lead to increased audit costs. Political conflicts (Deis et al. 1992) and competition between different political representatives and parties (Baber 1990; Cohen and Leventis 2013) raise demands for monitoring and auditing effort, implying increased audit fees.

The public viability and politicized environment may increase the reputation risk and audit effort for auditors (Redmayne et al. 2010; Cohen and Leventis 2013). In a Swedish context where the risk of litigation is perceived as low (Svanström 2013; Alexeyeva and Svanström 2015) auditors still have incentives to maintain high audit quality in order to avoid reputational losses (Skinner and Srinivasan 2012). ${ }^{1}$ As a

\footnotetext{
1 In cases involving the Supreme Court in Sweden, the claims against the auditor have to be solid if plaintiffs should be able to get compensation of damage (Aspholm 2002). In addition to the Supreme Court, out-of-court settlements and other court cases may also affect the auditors' behavior (Zerni et al. 2012).
} 
consequence of bad publicity (for example, related to a low-quality audit within a municipal company or a company failure) the public may lose the confidence, both in the auditor and in the financial reports of the company (Barton 2005). Regarding negative media exposure due to unethical behaviour, the hybridisation has reduced the ability for citizens to get access to public documents, as municipal corporations need to consider both public and civil law (Gissur O Erlingsson et al. 2008; Shaoul et al. 2012). According to Agrento et al. (2010) this can sometimes create conflicts, as the legislation for corporations and local governments are based on different presumptions. A lower degree of transparency increases the risk of corrupt behaviour and abuse of power (Linde and Erlingsson 2013). In the end this affects the auditor who is responsible for considering the risk of material misstatement due to error and fraud (DeZoort and Harrison 2016). Maintaining public confidence is essential as the audit process is largely non-transparent and it is impossible for a third party to assess the quality of a given audit (Hennes et al. 2014). A loss in reputation for the audit firm will impair the ability to keep hold of current clients and attract new ones (Defond and Zhang 2014). Due to a greater demand for audit quality, Skinner and Srinivasan (2012) find evidence that larger clients and those with growth opportunities are more likely to leave an audit firm that have suffered from a reputational loss. Regarding the procurement of audit service for municipal corporation audit, firms have incentives to consider reputational risk when they submit tenders. Since there are limited opportunities to adjust audit fees "after the fact" to cover reputational losses, auditors need to act preventively and incorporate potential losses into the audit fee (Simunic and Stein 1996).

In the Swedish context, the principle of openness may increase the reputation risk, as may the fact that the municipal auditors have a right to appoint a lay auditor that (in addition to the external auditor) will express his or her own opinion about the adequacy of internal controls. When the auditor is aware that a lay auditor will perform a partly parallel audit, the auditor will probably be more careful in order to avoid the risk of making mistakes which are then detected by the lay auditor. One specific area that certainly will be audited by all appointed auditors and require special attention is internal controls (SALAR 2017). Accuracy requires time, which may lead to increased audit costs. Consequently, the combination of public and private characteristics of hybrid organizations may lead to additional audit effort and thus increased audit fees.

However, according to Jensen et al. (2005), agency costs are sometimes perceived to be less prevalent in the municipal sector than in the private sector. The character of public property reduces the incentives for monitoring (Zimmerman 1977). Even though municipal corporations, in a sense, are private organizations that must comply with company law, accountability is claimed in a municipal context, a context where the degree of formal accountability in general is low (Knutsson et al. 2012). Reduced accountability within hybrid organizations (Billis 2010; André 2010) can partly be explained by the occurrence of different principal-agent relationships that are complex due to diverge expectations and demands from different stakeholders (Thomasson 2009b; Shaoul et al. 2012; Kankaanpää et al. 2014; Grossi and Thomasson 2015). An accountability gap thus exists (Sands 2006), which complicates the governance of the hybrid organization and creates an opportunity for managers and auditors to act in their 
own self-interest. A perceived low degree of accountability decreases the litigation risk and from a wealth maximization perspective the auditor will "perform an audit which will reduce the chance of a successful negligence suite to a level which is acceptable" (Sherer and Turley 1997 p. 60). Consequently, the combination of reduced accountability and a low litigation risk may lead to reduced audit effort and thus lower audit fees.

Regarding business risk, previous research (Bell et al. 2001; Niemi 2002; Kim and Fukukawa 2013) show that auditors respond to higher business risk either by increasing audit effort (increase in audit hours or use of more experienced staff) or by charging a risk premium (no increase in audit effort) which will cover potential losses. More specifically, client business risk is related to a wide spectrum of different factors (industry conditions, organizational structure and business processes) that all have the potential to affect the client's ability to achieve its objectives (Erickson et al. 2000; Bell et al. 2008; Stanley 2011; Kim and Fukukawa 2013). Ultimately, the concept of client business risk is "associated with the entity's survival" (Bell et al. 1997 p.15) both in the short and long term. Based on Markowitz (1952) and modern portfolio theory, it can be argued that municipal corporations have a higher business risk compared to private firms, as they are unable to allocate assets to other geographical areas or differentiate among different classes of property (Viezer 2000; Boverket 2017). Private corporations are more adaptive to changed market conditions as they to a greater extent acquire and sell properties (Boverket 2017). From an audit perspective, executed acquisitions would likely have an impact on the risk assessment procedure and create an increased demand for additional audit. (ISA, 315). However, considering that the municipal corporations have a financially strong owner with almost endless resources due to its taxation capacity (Chan 2003; Jones and Pendlebury 2004) the debt side of capital can be expected to attract little attention since there is a credible tradition that municipal corporations do not go bankrupt (Collin and Tagesson 2010). Hence, the business risk of the municipal corporations must be considered as low, and in the end result in lower audit fees. By focusing on the financial statements and the administration of the management (according to ISA and generally accepted auditing standards in Sweden) the external auditors are able to restrict their mission and crucial parts of the hybrid complexity will be handled by the lay auditors.

In sum; the political and hybrid characteristics of the municipal corporation indicate a potential reputational risk that may lead to increased audit fees. However, on the other hand the municipal ownership implies a low business risk which suggests decreased audit fees.

Given the lack of directional clarity, we state the hypothesis to be tested in null form. We propose:

H1 Municipal ownership does not affect and determine audit fees. 


\section{Method and empirical setting}

\subsection{The Swedish setting}

Swedish municipalities are quite autonomous regarding the direction and organization of local activities (Agrento et al. 2010). Thus, municipal activities can be organized and carried out through municipal corporations (ibid.). Besides direct management, corporatizations in the form of municipally owned joint stock corporations are the dominating organizational form of local public service providers in Sweden (Agrento et al. 2010). Today there are approximately 1600 joint stock corporations that are wholly or partly owned by one or more of the 290 Swedish municipalities. The balance sheet total of the municipality-owned enterprises amounted in 2014 to SEK 1163 billion with an equity-assets ratio of $21.6 \%$ (SCB 2014). Thus, a large part of the municipalities' wealth and total assets are controlled by these corporations (e.g. Tagesson and Grossi 2012). This can be explained by the fact that operation and ownership of municipal buildings, real estate and public housing very often are organized in municipal corporations (Collin et al. 2009). Anyhow, both in terms of number and size, municipal corporations constitute an important part of the Swedish audit market. They combine organisational characteristics from both the private and public sector (Grossi and Thomasson 2015) and are subject to both municipal and private law. In addition to the general legislation for limited corporations, including audit requirements, municipal corporations are also subject to certain rules of the Municipal Act (e.g. Haraldsson 2017). For example, (1) without explicit legal support, municipal corporations are forbidden to organize with the subject of making a profit, (2) the municipal auditors have the right to appoint a lay auditor in addition to the auditor who is responsible for corporate audit and (3) the corporations are, just like the municipalities, subject to the principle of openness, which means that citizens basically have the right to access all documents concerning the company.

Within wholly owned municipal corporations it is actually statutory, according to the Swedish Local Government Act (1991:900), to appoint at least one lay auditor. In municipal corporations, lay auditors are elected among, or in consultation with, the municipal auditors. This means that the assignment is carried out by or in close collaboration with the municipal auditors (SALAR 2017). The task of the lay auditor is to review whether the company works in accordance with the owner's (municipality's) intention and goals, whether the activity is effective and if the internal control is sufficient (Companies Act 2005; SALAR 2017). The lay auditor submits a separate report to the Annual General Meeting.

\subsection{Data}

The empirical data in this study consist of 249 Swedish municipal corporations and 240 private corporations within the real estate and housing industry. In order to locate municipality-owned public housing corporations, the Swedish Association of Public Housing Companies (SABO) was contacted. SABO provided a list of 300 member corporations that are owned by municipalities and managed as limited 
corporations. Out of the initial 300 municipal corporations, 51 were excluded due to lack of data. All financial data connected to the 249 municipal corporations were collected through the annual reports for year 2012.

Contact information of the private housing corporations was gathered through the websites of the municipalities. Municipalities have a duty to disclose information about private housing corporations that operate within the municipality. In total, financial data of 240 private housing corporations were collected through both annual reports and a database called Retriever Business. Additionally, to the financial data, five interviews were conducted with partners from the Big-4 audit firms and Grant Thornton.

\subsection{Research design}

As mentioned in the introduction, we build our analysis on Simunic (1980) taking into consideration the audited organization as well as the audit market. Simunic's basic audit pricing study is regarded as a seminal work and which has profoundly influenced subsequent research (Cobbin 2002; Hay et al. 2006). In order to examine the competitiveness within the audit market (price differences between Big 8 and non-Big 8 audit firms), Simunic developed an audit fee model that could be used to investigating the determinants of audit fees. The results of the study show that audit fees are significantly associated with a large number of different factors which essentially can be related to the size, risk and complexity of the auditee. Regarding audit market competition, Simunic does not find any significant results supporting a big- 8 premium and monopoly pricing. The original audit fee model has been subject to a number of different modifications (new explanatory variables) and has been tested in a large number of different institutional environments (Cobbin 2002; Hay et al. 2006; Hay 2013). In a Nordic context, different modified versions of the original audit fee model have been used to determine the audit fees within private corporations (Hope and Langli 2010; Sundgren and Svanström 2013), public corporations (Zerni et al. 2012; Holm and Thinggaard 2014) and municipalities (Johnsen et al. 2004; Collin et al. 2017).

In addition to the statistical analysis, qualitative interviews have been conducted in order to get a better understanding of the studied phenomena. By using multiple data sources, access to more detailed empirical data was obtained that could be used to improve the validity of the results (Patton 2002; Eisenhardt 1989). The use of a sequential explanatory strategy made it possible to further interpret the statistical results and put forward alternative explanations that could be used to refine current theories (Creswell 2009). The interviews were semi-structured, implying that they were based on an interview guide that contained open-ended questions. In total, interviews were conducted with five partners from five different audit firms. More specifically, the respondents represented each of the Big-4 audit firms and Grant Thornton. The respondents were selected with regard to representativeness, previous experience and specific qualities (Alvesson 2011). As more than $80 \%$ of all corporations in the sample were audited by a Big-4 audit firm it was essential, with regard to representativeness, to mainly select respondents from those firms. The use 
of highly knowledgeable individuals (partners) were necessary as they have experience regarding pricing of audit services, both in municipal and private corporations. Regarding the analysis of the empirical data, the focus has been on the manifest statements, with emphasis on the actual meaning (e.g. Neuendorf 2002). The use of open-ended questions made it appropriate to use structural coding which directed the analysis to the specific research questions (Saldaña 2009). The aim of the interviews has been to obtain a better understanding and to further test the reliability of our statistical analysis (Falkman and Tagesson 2008).

\subsubsection{Dependent variable}

In accordance with Simunic (1980) and subsequent studies (Firth 1997; Niemi 2002; Thinggaard and Kiertzner 2008), the total audit fees were used as dependent variable. Following the majority of previous studies (Hay et al. 2006) total audit fees were transformed by using the natural logarithm (AFEE).

\subsubsection{Independent variable}

Given the aim of this study, the independent variable was operationalized as a dummy variable where 1 denotes a municipal ownership and 0 a private ownership (MUNICIPAL_OWN).

\subsubsection{Control variables}

Meta-analyses by Hay et al. (2006) and Hay (2013) emphasize that client size is the most important determinant of audit fees and included in almost all studies. The size of the corporation was operationalized by using total assets (ASSETS) and, like AFEE, transformed by using the natural logarithm.

Inventory and receivables are two types of assets that are associated with increased inherent risk due to large volumes and fraud opportunities (Firth 1997). Inventory and receivables were divided by total assets (INVREC) (Ahmed and Goyal 2005; Niemi 2005; Griffin et al. 2009).

Due to a large number of corporations with less than two subsidiaries the square root of the total number of subsidiaries was not used as a proxy for complexity. Instead, client complexity was operationalized as a dummy variable where corporations that have at least one subsidiary been coded 1, and corporations without any subsidiary 0 (SUBS). The possession of subsidiaries causes increased travel and coordination expenses for the auditor and obliges the auditor to learn more about the new organization and its operations (Firth 1997). The debt to equity ratio (DE) was used as a measure of leverage. Increased leverage is associated with higher risk of bankruptcy and thus also higher financial risk for the auditor (Nikkinen and Sahlström 2004). Another risk measure connected to the auditor is the occurrence of a modified audit opinion. Corporations that received a modified audit opinion were coded 1 and corporations with a clean opinion 0 (Francis and Stokes 1986) (OPINION). 
Following previous studies by Niemi (2002) and Casterella et al. (2004), the occurrence of financial losses was operationalized with a dummy variable, where 1 denotes that the company has reported a negative net income during any of the last 2 years (LOSS). Corporations that possess a financial guarantee exclude the risk of bankruptcy and decrease the probability that an auditor will suffer financial losses. Corporations that obtain a financial guarantee were coded 1 , and other corporations 0 (GUARANTEE). Audit firm tenure and possible lowballing (DeAngelo 1981) were measured by a dummy variable. Corporations that changed their signing audit firm during either of the last 2 years were coded 1 and if no change occurred were coded 0 (AUDCHA). Free cash flow was measured as operating income before depreciation minus taxes and interest payments (Nikkinen and Sahlström 2004). As in previous studies (Gul and Tsui 1998, 2001; Nikkinen and Sahlström 2004), free cash flow was divided by total assets (FCF).

Non-audit services were operationalized as a dummy variable where corporations that purchased non-audit services from their incumbent audit firm were coded 1, and if not 0 (NAS). In order to control for a potential fee premium, individual proxies were used for each of the Big-4 audit firms (KPMG, EY, DELOITTE, PWC), and other audit firms were merged into one category (OAF). PWC was used as reference variable (Table 1). Two separate dummy variables were used to separate municipal corporations and private corporations audited by PWC (PWC_MUNICIPAL, PWC_PRIVATE). Our main audit fee model has the following structure:

$$
\begin{array}{r}
\text { AFEE }=\alpha+\beta_{1} \text { MUNICIPAL_OWN }+\beta_{2} A S S E T S+\beta_{3} I N V R E C+\beta_{4} S U B S+\beta_{5} D E \\
+\beta_{6} \text { OPINION }+\beta_{7} L O S S+\beta_{8} G U A R A N T E E+\beta_{9} A U D C H A+\beta_{10} F C F \\
+\beta_{11} N A S+\beta_{12} \text { KPMG }+\beta_{13} E Y+\beta_{14} D E L O I T T E+\beta_{15} O A F \\
+\beta_{16} P W C \_M U N I C I P A L+\beta_{17} P W C \_P R I V A T E+e
\end{array}
$$

\section{Analysis and findings}

\subsection{Findings from quantitative analysis}

The descriptive statistics are presented in Table 2. The table includes descriptive statistics of all variables used in the audit fee models.

As shown in Table 2, the total sample of 489 corporations consists of 249 (50.9\%) municipal and $240(49.1 \%)$ private corporations. The mean of AFEE and ASSETS is 4.6 (12.8) with a standard deviation of 1.02 (1.57). $46 \%$ of all corporations have at least one subsidiary and $3 \%$ of the total assets consist of inventory and receivables. Only $1.4 \%$ of all corporations in the sample received a modified audit opinion during year 2012 and a little more than 50 corporations were secured by a financial guarantee. During the period 2011-2012, 24.1\% of all corporations reported a negative net income and during the same period $5.5 \%$ or 27 corporations changed their signing audit firm.

In 2012, almost three quarters $(74.4 \%)$ of all corporations purchased non-audit services from their incumbent audit firm. More than $35 \%$ of all corporations in the 
Table 1 Definitions of variables used in the regression model

\begin{tabular}{|c|c|}
\hline Variable name & Definition \\
\hline \multicolumn{2}{|l|}{ Dependent variable } \\
\hline AFEE & Natural logarithm of total audit fees \\
\hline \multicolumn{2}{|l|}{ Independent variable } \\
\hline MUNICIPAL_OWN & $(0,1)$ variable, where 1 denotes a municipal corporation \\
\hline \multicolumn{2}{|l|}{ Control variables } \\
\hline ASSETS & Natural logarithm of total assets \\
\hline INVREC & Inventory and receivables divided by total assets \\
\hline SUBS & $(0,1)$ variable, where 1 denotes if the company has at least one subsidiary \\
\hline $\mathrm{DE}$ & Debt to equity ratio \\
\hline OPINION & $\begin{array}{l}(0,1) \text { variable, where } 1 \text { denotes if the company has received a modified audit } \\
\text { opinion }\end{array}$ \\
\hline LOSS & $\begin{array}{l}(0,1) \text { variable, where } 1 \text { denotes if the company has reported a negative net income } \\
\text { during any of the last three years }\end{array}$ \\
\hline GUARANTEE & $(0,1)$ variable, where 1 denotes if the company has a financial guarantee \\
\hline AUDCHA & $\begin{array}{l}(0,1) \text { variable, where } 1 \text { denotes if the company has changed the signing audit firm } \\
\text { during any of the last two years }\end{array}$ \\
\hline FCF & Free cash flow divided by total assets \\
\hline NAS & $\begin{array}{l}(0,1) \text { variable, where } 1 \text { denotes if the company has purchased non-audit services } \\
\text { from the incumbent audit firm }\end{array}$ \\
\hline KPMG & $(0,1)$ variable, where 1 denotes that KPMG is the signing audit firm \\
\hline EY & $(0,1)$ variable, where 1 denotes that $\mathrm{EY}$ is the signing audit firm \\
\hline DELOITTE & $(0,1)$ variable, where 1 denotes that Deloitte is the signing audit firm \\
\hline OAF & $\begin{array}{l}(0,1) \text { variable, where } 1 \text { denotes that a non-Big four audit firm is the signing audit } \\
\text { firm }\end{array}$ \\
\hline PWC_MUNICIPAL & $\begin{array}{l}(0,1) \text { variable, where } 1 \text { denotes a municipal corporation with PWC as signing } \\
\text { audit firm }\end{array}$ \\
\hline PWC_PRIVATE & $\begin{array}{l}(0,1) \text { variable, where } 1 \text { denotes a private corporation with PWC as signing audit } \\
\text { firm }\end{array}$ \\
\hline
\end{tabular}

sample have PWC as their signing audit firm. A market share of more than $44 \%$ for municipal corporations and of $26 \%$ for private corporations makes PWC a market leader among all of the audit firms. EY has a market share of $21.7 \%$, followed by other audit firms 18.4\%, KPMG 17.4\% and DELOITTE 6.7\%.

As shown in Table 3, a correlation matrix was conducted in order to examine correlation between the variables in the model. The dependent variable AFEE has a strong positive correlation with ASSETS (.689) and a more moderate positive correlation to SUBS (.456) and NAS (0.211). Considerable correlation, close to 0.7 , can be observed between some of the independent variables; to examine potential problems with multicollinearity, a variance inflation factor test was performed. All of the VIF-values are below 2.5 with a maximum VIF-value of 1.636 for model 1 and 2.173 for model 2. Low VIF-values decrease the likelihood of serious multicollinearity. 
Table 2 Descriptive statistics $(n=489)$

Variables

Dependent variable

Natural logarithm of total audit fees SEK (AFEE) Mean/S.D

4.60/1.02

Independent variable

Municipal corporation (MUNICIPAL_OWN)

$249(50.9 \%)$

Yes (1)

$240(49.1 \%)$

No (0)

Control variables

Natural logarithm of total assets SEK (ASSETS) Mean/S.D.

$12.84 / 1.57$

Inventory and receivable divided by total assets (INVREC) Mean/S.D

0.03/0.09

Corporations that have at least one subsidiary (SUBS)

$225(46.0 \%)$

Yes (1)

$264(54.0 \%)$

No (0)

Debt to equity ratio (DE) Mean/S.D.

$15.6 / 77.52$

Modified audit opinion (OPINION)

$7(1.4 \%)$

Yes (1)

$482(98.6 \%)$

No (0)

$118(24.1 \%)$

Negative net income during any of the last two years (LOSS)

$371(75.9 \%)$

$52(10.6 \%)$

Corporations possessing an financial guarantee (GUARANTEE)

Yes (1)

$27(5.5 \%)$

Change of signing audit firm during any of the last two years (AUDCHA)

$0.04 / 0.06$

Free cash flow divided by total assets (FCF) Mean/S.D

Non-audit services purchased from incumbent audit firm (NAS)

Yes (1)

No (0)

Audit firm

PwC (PWC)

$175(35.8 \%)$

KPMG (KPMG)

EY (EY)

$106(21.7 \%)$

Deloitte (DELOITTE)

$33(6.7 \%)$

Other audit firms (OAF)

Municipal corporations with PWC as signing audit firm PWC (PWC_MUNICIPAL)

Private corporations with PWC as signing audit firm (PWC_PRIVATE)

Table 4 presents the results from the different regression (ordinary least squares) models, where model 1 and 2 use MUNICIPAL_OWN as an independent variable. Both model 1 and 2 have an adjusted $\mathrm{R}^{2}$ value of $59.7 \%$, significant F-statistics (0.000), 489 observations and VIF-values lower than 2.5. In model 1, each of the Big-4 audit firms was treated separately and other audit firms were merged into one category (OAF). PWC was used as a reference variable. In model 


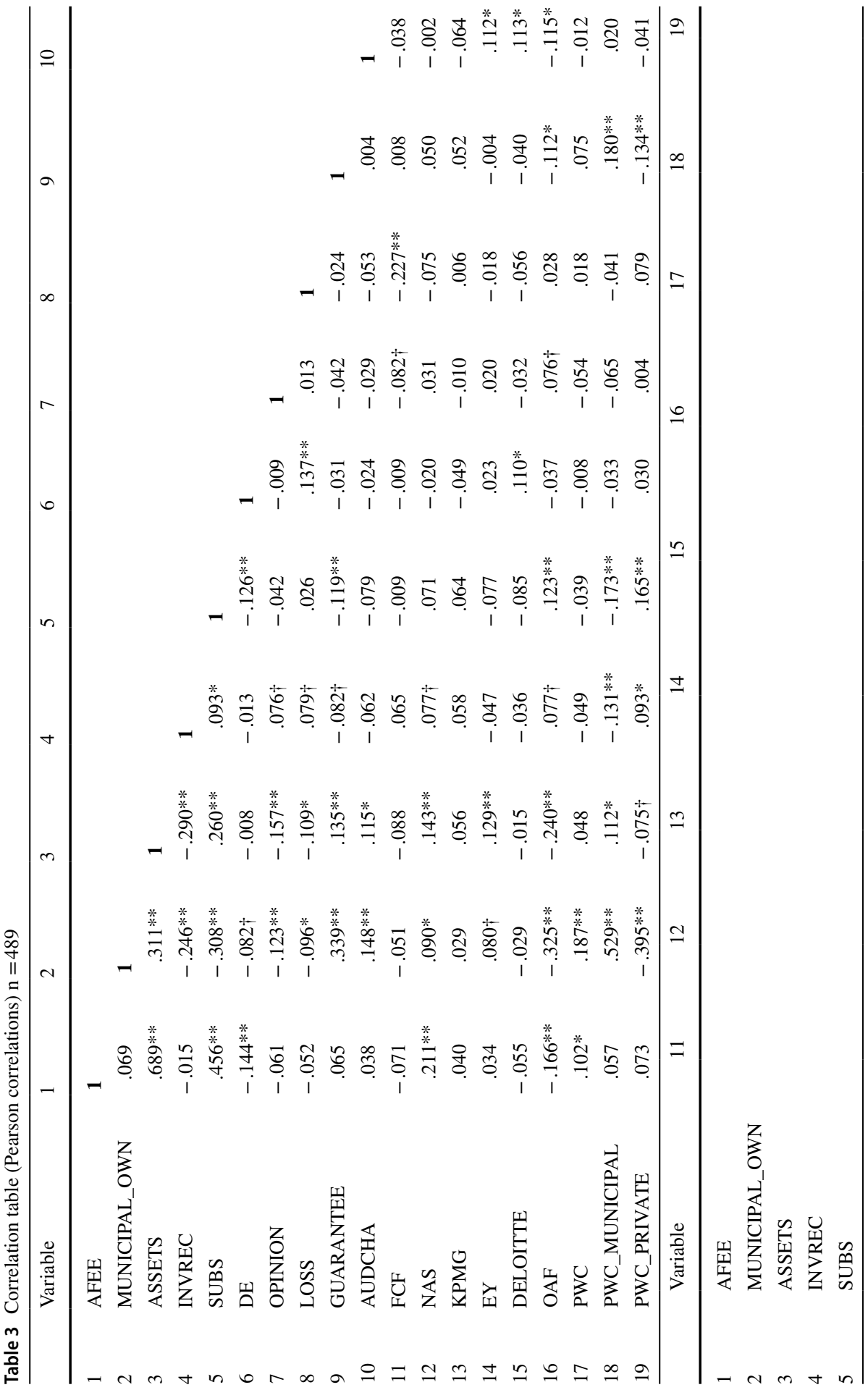




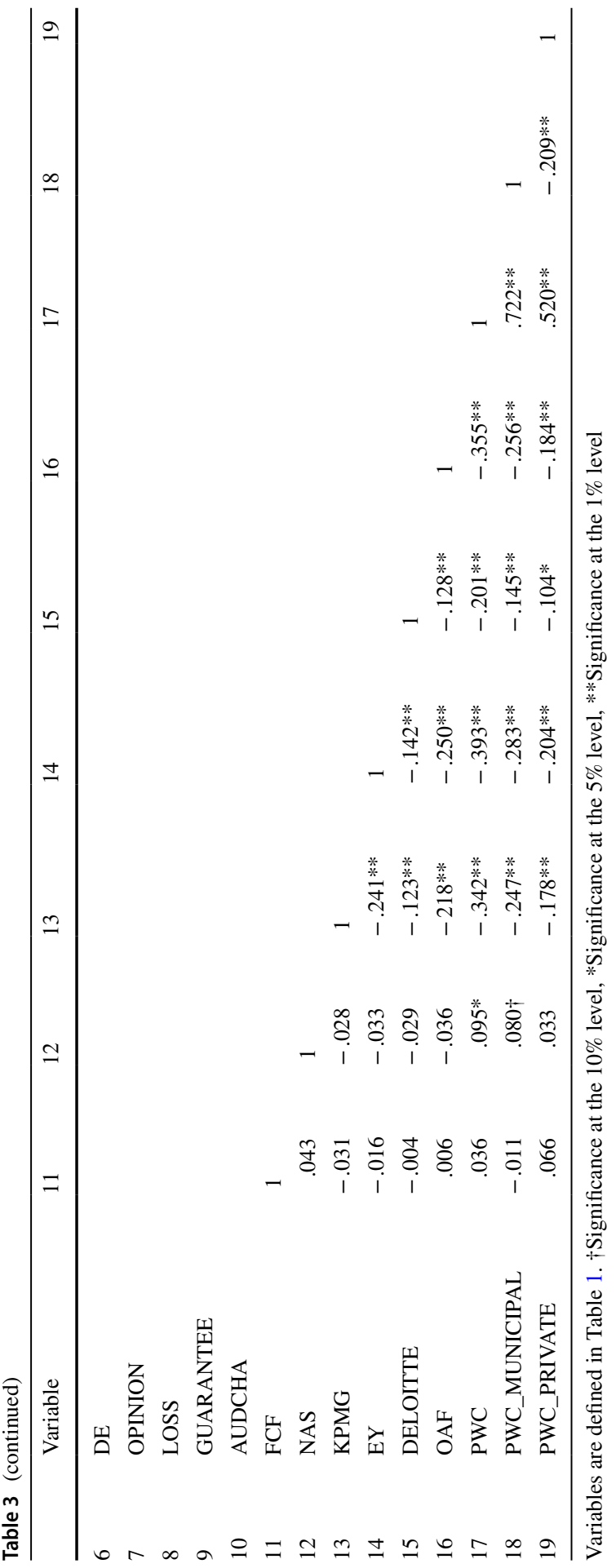




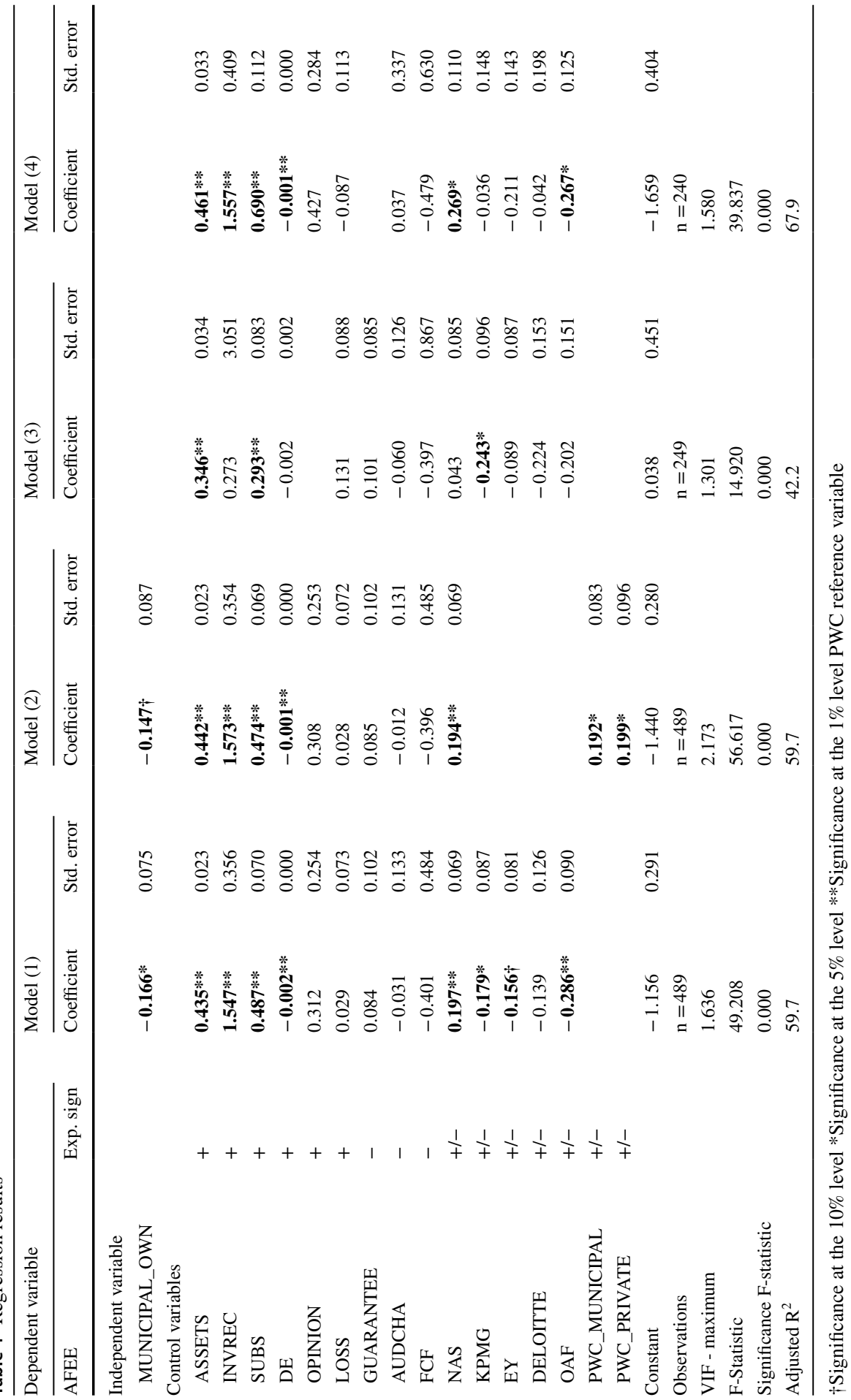


2, two new control variables were included in order to examine whether PWC was able to charge an audit fee premium both in municipal corporations and private corporations.

According to the results of both model 1 and model 2, we reject the null hypothesis that municipal ownership does not affect and determine audit fees. In both models, municipal corporations pay approximately $15 \%$ lower audit fees compared to private corporations. Of the control variables, ASSETS, INVREC, SUBS and NAS show a significant positive relationship with the audit fees on a $1 \%$ level and DE a significant negative relationship on a $1 \%$ level. Compared to the non-Big 4 audit firms, PWC charges an audit fee premium of nearly $25 \%$ and compared to KPMG $16 \%$. It is evident that PWC charges higher audit fees compared to all other audit firms (except DELOITTE) in the sample. In model 2, we find that PWC, compared to the other audit firms, charges higher audit fees both within municipal corporations and private corporations.

In order to further examine the determinants of audit fees at a more disaggregate level, we separated the full sample with regard to municipal (model 3) and private corporations (model 4). As none of the municipal corporations received a modified audit opinion during 2013, model 3 does not include OPINION as a control variable. For a similar reason, model 4 lacks GUARANTEE as a control variable. A comparison of the adjusted R-square values shows that there exist large differences between model 3 and 4, the explanatory power of the audit fee model is noticeably higher for private corporations $(67.9 \%)$ than municipal corporations $(42.2 \%)$. Even with regard to the audit fee determinants there exist significant differences between the audit fee models. The regression results show that two of the variables, ASSETS and SUBS, have significant positive coefficients, both in model 3 and 4. However, in model 4, additionally three variables show a significant relationship with the audit fees, INVREC and NAS have a significant positive relationship with the audit fees and DE a significant negative relationship. In model 3, PWC manages to charge higher audit fees compared to KPMG, and in model 4, compared to the non-Big 4 audit firms.

\subsection{Findings from the interviews}

One of the interviewed partners explicitly pointed out that there is an increased reputation risk to accept the audit of a municipal corporation, since these corporations often are closely examined and scrutinized by mass media:

If it is a municipal corporation the audit firm can be very exposed. If something happens in a municipal corporation it will cause a lot of media attention in different ways. This attention will affect the audit firm negatively. Therefore, the audit firm needs to consider a risk premium which takes into account negative media exposure, even if it's not directly connected to their assignment. (Partner 3)

However, four out of five partners claimed that the audit fees should be lower in municipal corporations due to a reduced business risk and procurements of audit 
services. Municipal corporations normally have a good financial position, high solidity and in addition they also have dividend restrictions. One of the partners pointed out that municipal corporations do not acquire and sell properties to the same extent as private corporations, which is of great importance in the assessment of the business risk:

Regarding purchase and sale of real estate, there is not as much business happening in the municipal corporations as in the private corporations. Thus, you do not need to put as much focus on valuation issues in the municipal corporations. (Partner 1)

Regarding reputation risk he pointed out that during an audit you always select and evaluate samples of risk items for compliance and testing purposes. If you then find errors, this might imply increase in audit effort and indirectly higher audit fees. Regarding municipal corporations he especially pointed at the media's interest for investigating and report on representation and study visits. Even if an error is not material per se, the political nature of the auditee can justify and motivate an extended review.

Another explanation why audit fees are lower in municipal corporations than in private corporations, which emerged during the interviews, was that municipalities are able to push prices by coordinating procurements for the municipality and the municipal corporations:

We have a somewhat standardized procedure regarding what we need to spend time on when we perform an audit. We evaluate how many members, specialists and experts that need to be a part of the team to carry out the audit assignment. [...] Then we have to adapt the tender considering the market conditions. Based on all this we decide upon an indicative price. We are not allowed to offer a fixed price by law. (Partner 3)

If an audit firm win the tender both regarding the assistance of the municipal auditors (e.g. lay auditors) and the corporation, it is easier to coordinate the work between lay auditor and external auditor. According to the respondents this is the most common scenario and the interviews revealed that the external audit and the lay man audit usually are coordinated.

Normally I meet the layman auditor and his assistant at least twice a year to coordinate the work. Usually, the auditor who assists the layman auditor is from the same audit firm as I, which facilitates the work. (Partner 1)

\section{Discussion and conclusions}

The aim of the study was to examine whether municipal ownership is a factor that affects and determines audit fees. Our analyses clearly show that municipal housing corporations pay significantly lower (approximately 15\%) audit fees than privately owned corporations in the same industry. One conclusion, based on this result, is that the audit firms price business risk and litigation risk higher than the reputation 
risk associated with the public viability and politicized environment of municipal corporations. Based on the results of this study and existing theory, lower audit fees within municipal corporations may be explained by four important aspects. First, a reduced number of property transactions will likely reduce the business risk and lead to lower audit effort. In contrast, executed acquisitions will lead to increased audit effort as more work is required and performed by senior managers and specialists. The second and third aspect concern reduced accountability within municipal corporations (Grossi and Thomasson 2015), and a low litigation risk which imply an opportunity for auditors to act in their own self-interest. The occurrence of an accountability gap thus increases the likelihood that self-interested auditors will limit the scope of their work and perform an audit that is below average standard. Fourth, our interviews reveal that municipal corporations are able to push down audit fees as a result of the procurement process. This is further supported by Tagesson et al. (2015) who find evidence that price is a predominant criterion when municipalities procure audit services. Thus, it is possible that audit firms use a low-balling strategy to gain market shares or to retain important clients. Regarding reputation risk, the interviews indicated that it is a factor that always needs to be considered when the auditor selects items for evaluation and testing. However, if an error is detected in a municipal corporation, the auditor has to consider not only materiality but also the political implications.

As an industry leader, PWC manages to charge an audit fee premium of 15-25\% compared to the majority of the audit firms used in the sample; a division between municipal corporations and private corporations shows that PWC exhibits a higher fee premium for private corporations. From a neoclassical perspective, a fee premium can be explained by superior audit quality, which justifies higher audit fees. Another plausible explanation is that PWC holds a unique market position with a large distance to its closest competitors (Numan and Willekens 2012). Insignificant results regarding the possession of a financial guarantee can be explained by the fact that it is very rare that a Swedish municipal corporation goes bankrupt. Regarding municipal corporations, the signing auditor is exposed to possible reputation loss rather than high financial risk.

Regarding the results of the different audit fee models, there exists a general explanatory power which applies to both municipal and private corporations. However, the audit fee model seems to be more adapted to private sector organizations as the adjusted $\mathrm{R}^{2}$ is significantly higher for private corporations $(67.9 \%)$ compared to municipal corporations (42.2\%). Previous research (Hope and Langli 2010; Sundgren and Svanström 2013) show that the explanatory power of the audit fee model is reduced when shifting focus from public $(80-85 \%)$ to private $(50-55 \%)$ corporations. These results indicate that a well specified model for public corporations is reduced in explanatory power when transformed to other contexts. For example, considering municipal corporations the audit fee model could probably be developed further and adapted in order to consider municipal corporations' conditions and characteristics of hybrid organization. Thus, the present study has some limitations and identifies some suggestions for future research. Our statistical model lacks a theory of interest group intermediation. As indicated by the interviews, a reasonable assumption is that interest groups, such as the media, are directed by their own 
interests and could even be assumed to influence the risk assessment and pricing of audit services in hybrid organizations (Redmayne et al. 2010). Another factor that emerged from the supplementary interviews with the partners from the audit firms was the municipal negotiation power due to coordinated procurements for the municipality and the municipal corporations. In a model designed to explain the audit fees in municipal corporations, this factor may be operationalized by the variables (1) total number of corporations in the municipal group and (2) the municipal budget for audit services.

Open Access This article is distributed under the terms of the Creative Commons Attribution 4.0 International License (http://creativecommons.org/licenses/by/4.0/), which permits unrestricted use, distribution, and reproduction in any medium, provided you give appropriate credit to the original author(s) and the source, provide a link to the Creative Commons license, and indicate if changes were made.

\section{References}

Agrento, D., Grossi, G., Tagesson, T., \& Collin, S.-O. (2010). The 'externalisation' of local public service delivery: experience in Italy and Sweden. International Journal of Public Policy, 5(1), 41-56.

Ahmed, K., \& Goyal, M. (2005). A comparative study of pricing of audit services in emerging economies. International Journal of Auditing, 9(2), 103-116.

Alexeyeva, I., \& Svanström, T. (2015). The impact of the global financial crisis on audit and non-audit fees. Managerial Auditing Journal, 30, 302-321.

Alvesson, M. (2011). Intervjuer-Genomförande, tolkning och reflexivitet. Malmö: Liber.

André, R. (2010). Assessing the accountability of government-sponsored enterprises and quangos. Journal of Business Ethics, 97(2), 271-289.

André, P., Broye, G., Pong, C., \& Schatt, A. (2016). Are joint audits associated with higher audit fees? European Accounting Review, 25(2), 245-274.

Aspholm, I. (2002). Rättsekonomisk analys av revisors skadeståndsansvar $i$ Norden [Legal analysis of the auditor's liability in the Nordic countries]. Helsinki: Hanken School of Economics, Department of Accounting and Commercial Law, Commercial Law.

Baber, W. R. (1983). Toward understanding the role of auditing in the public sector. Journal of Accounting and Economics, 5(3), 213-227.

Baber, W. R. (1990). Toward a framework for evaluating the role of accounting and auditing in political markets: The influence of political competition. Journal of Accounting and Public Policy, 9(1), 57-93.

Baber, W. R., Brooks, E. H., \& Ricks, W. E. (1987). An empirical investigation of the market for audit services in the public sector. Journal of Accounting Research, 25(2), 293-305.

Barton, J. (2005). Who cares about auditor reputation? Contemporary Accounting Research, 22(3), $549-586$.

Basioudis, I. G., \& Ellwood, S. (2005a). An empirical investigation of price competition and industry specialisation in NHS audit services. Financial Accountability and Management, 21(2), 219-247.

Basioudis, I. G., \& Ellwood, S. (2005b). External audit in the national health service in England and Wales: A study of an oversight body's control of auditor remuneration. Journal of Accounting and Public Policy, 24(3), 207-241.

Bell, T. B., Doogar, R., \& Solomon, I. (2008). Audit labor usage and fees under business risk auditing. Journal of Accounting Research, 46(4), 729-760.

Bell, T. B., Landsman, W. R., \& Shackelford, D. A. (2001). Auditors' perceived business risk and audit fees: Analysis and evidence. Journal of Accounting Research, 39(1), 35-43.

Bell, T. B., Marris, F. O., \& Solomon, I. (1997). Auditing organizations through a strategic systems lens. Montvale, NJ: KPMG LLP. 
Billis, D. (2010). Towards a theory of hybrid organizations. In D. Billis (Ed.), Hybrid organizations and the third sector: challenges for practice, theory and policy. Basingstoke, Hampshire, UK: Palgrave Macmillan.

Boverket. (2017). Allmännyttiga kommunala bostadsaktiebolag—utvärdering av tillämpningen av gällande lagstiftning, 2017, Boverket.

Calabró, A., Torchia, M., \& Ranalli, F. (2013). Ownership and control in local public utilities: The Italian case. Journal of Management and Governance, 17(4), 835-862.

Casterella, J. R., Francis, J. R., Lewis, B. L., \& Walker, P. L. (2004). Auditor industry specialization, client bargaining power, and audit pricing, auditing. A Journal of Practice and Theory, 23(1), $123-140$.

Chan, J. L. (2003). Government accounting: an assessment of theory, purposes and standards. Public Money and Management, 23(1), 13-20.

Cobbin, P. E. (2002). International dimensions of the audit fee determinants literature. International Journal of Auditing, 6, 53-77.

Cohen, S., \& Leventis, S. (2013). An empirical investigation of audit pricing in the public sector: The case of Greek LGOs. Financial Accountability \& Management, 29(1), 74-98.

Collin, S.-O., Haraldsson, M., Tagesson, T., \& Blank, V. (2017). Explaining municipal audit costs in Sweden: Reconsidering the political environment, the municipal organisation and the audit market. Financial Accountability \& Management, 33, 391-405.

Collin, S.-O., \& Tagesson, T. (2010). Governance strategies in local government: a study of governance of municipal corporations in a Swedish municipality. International Journal of Public Policy., 5(4), 373-389.

Collin, S.-O., Tagesson, T., Andersson, A., Cato, J., \& Hansson, K. (2009). Explaining the choice of accounting standards in municipal corporations. Critical Perspectives on Accounting, 20(2), $141-174$.

Creswell, J. W. (2009). Research design. Qualitative, quantitative and mixed methods approaches. Thousand Oaks: Sage.

DeAngelo, L. E. (1981). Auditor independence, "low balling", and disclosure regulation. Journal of Accounting and Economics, 3(2), 113-127.

DeFond, M., \& Zhang, J. (2014). A review of archival auditing research. Journal of Accounting and Economics, 58(2), 275-326.

Deis, D. R., \& Giroux, G. A. (1992). Determinants of audit quality in the public sector. The Accounting Review, 67(3), 462-479.

DeZoort, F. T., \& Harrison, P. D. (2016). Understanding auditors' sense of responsibility for detecting fraud within organizations. Journal of Business Ethics. https://doi.org/10.1007/s10551-016-3064-3.

Eisenhardt, K. M. (1989). Building theories from case study research. The Academy of Management Review, 14(4), 532-550.

Erickson, M., Mayhew, B. W., \& Felix, W. L. (2000). 'Why do audit fail?' Evidence from Lincoln savings and loan. Journal of Accounting Research, 38(1), 165-194.

Erlingsson, G. Ó., Bergh, A., \& Sjölin, M. (2008). Public corruption in Swedish municipalities-Trouble looming on the horizon? Local Government Studies, 34(5), 585-603.

Falkman, P., \& Tagesson, T. (2008). Accrual accounting does not necessarily mean accrual accounting: Factors that counteract compliance with accounting standards in Swedish municipal accounting. Scandinavian Journal of Management, 24(3), 271-283.

Firth, M. (1997). The provision of non-audit services and the pricing of audit fees. Journal of Business Finance and Accounting, 24(3), 511-525.

Francis, J. R., \& Stokes, D. J. (1986). Audit prices, product differentiation, and scale economics: Further evidence from the Australian market. Journal of Accounting Research, 24(2), 283-293.

Griffin, P. A., Lont, D. H., \& Sun, Y. (2009). Governance regulatory changes, international financial reporting standards adoption, and New Zealand audit and non-audit fees: Empirical evidence. Accounting and Finance, 49(4), 697-724.

Grossi, G., Reichard, C., Thomasson, A., \& Vakkuri, J. (2017). Editorial. Public Money \& Management, 37(6), 379-386.

Grossi, G., \& Thomasson, A. (2015). Bridging the accountability gap in hybrid organizations: The case of Copenhagen Malmö Port. International Review of Administrative Science, 81(3), 604-620.

Gul, F. A., \& Tsui, J. S. L. (1998). A test of the free cash flow and debt monitoring hypotheses: Evidence from auditing pricing. Journal of Accounting and Economics, 2(24), 219-237. 
Gul, F. A., \& Tsui, J. S. L. (2001). Free cash flow, debt monitoring, and audit pricing: Further evidence on the role of director equity ownership. Auditing: A Journal of Practice and Theory, 2(20), 71-84.

Haraldsson, M. (2017). When revenues are not revenues: The influence of municipal governance on revenue recognition within Swedish municipal waste management. Local Government Studies, 43(4), $668-689$.

Hay, D. (2013). Further evidence from meta-analysis of audit fee research. International Journal of Auditing, 17(2), 162-176.

Hay, D. C., Knechel, W. R., \& Wong, N. (2006). Audit fees: A meta-analysis of the effect of supply and demand attributes. Contemporary Accounting Research, 23(1), 141-191.

Hennes, K. M., Leone, A. J., \& Miller, B. P. (2014). Determinants and market consequences of auditor dismissals after accounting restatements. The Accounting Review, 89(3), 1051-1082.

Holm, C., \& Thinggaard, F. (2014). Leaving a joint audit system: Conditional fee reductions. Managerial Auditing Journal, 29(2), 131-152.

Hope, O., \& Langli, J. (2010). Auditor independence in a private firm and low litigation risk setting. The Accounting Review, 85(2), 573-605.

International Auditing and Assurance Standards Board. (2009). International Standard on Auditing (ISA) No. 315. Identifying and assessing the risks of material misstatement through understanding the entity and its environment. New York: IAASB.

Jansson, E. (2005). The stakeholder model: The influence of the ownership and governance structure. Journal of Business Ethics, 53(1), 1-13.

Jensen, K. L., \& Payne, J. L. (2005). Audit procurement: Managing audit quality and audit fees in response to agency costs. Auditing: A Journal of Practice and Theory, 24(2), 27-48.

Johnsen, Å., Meklin, P., Oulasvirta, L., \& Vakkuri, J. (2004). Governance structures and contracting out municipal auditing in Finland and Norway. Financial Accountability and Management, 20(4), 445-477.

Jones, R., \& Pendlebury, M. (2004). A theory of the published accounts of local authorities. Financial Accountability \& Management., 20(3), 305-325.

Kankaanpää, J., Oulasvirta, L., \& Wacker, J. (2014). Steering and monitoring model of state-owned enterprises. International Journal of Public Administration, 37(7), 409-423.

Kickert, W. J. M. (2001). Public management of hybrid organizations: Governance of quasi-autonomous executive agencies. International Public Management Journal, 4(2), 135-150.

Kim, H., \& Fukukawa, H. (2013). Japan's Big 3 firms' response to clients' business risk: Greater audit effort or higher audit fees? International Journal of Auditing, 17(2), 190-212.

Knutsson, H., Ramberg, U., \& Tagesson, T. (2012). Benchmarking through municipal benchmarking networks: Improvement or leveling of performance? Public Performance and Management Review, $36(1), 102-123$.

Linde, J., \& Erlingsson, G. Ó. (2013). The eroding effect of corruption on system support in Sweden. Governance, 26(4), 585-603.

Lindqvist, K. (2013). Hybrid governance: The case of household solid waste management in Sweden. Public Organizational Review, 13, 143-154.

Markowitz, H. (1952). Portfolio selection. The journal of finance, 7, 77-91.

Neuendorf, K. (2002). The content analysis guide book, Thousand Oaks. California: Sage Publications Inc.

Niemi, L. (2002). Do firms pay for audit risk? Evidence on risk premiums in audit fees after direct control for audit effort. International Journal of Auditing, 6(1), 37-51.

Niemi, L. (2005). Audit effort and fees under concentrated client ownership: Evidence from four international audit firms. The International journal of Accounting, 40(4), 303-323.

Nikkinen, J., \& Sahlström, P. (2004). Does agency theory provide a general framework for audit pricing? International Journal of Auditing, 3(8), 253-262.

Numan, W., \& Willekens, M. (2012). An empirical test of spatial competition in the audit market. Journal of Accounting and Economics, 53(1-2), 450-465.

Patton, M. Q. (2002). Qualitative research \& evaluation methods. Thousand Oaks: California, Sage publications Inc.

Redmayne, N. B., Bradbury, M. E., \& Cahan, S. F. (2010). The effect of political visibility on audit effort and audit pricing. Accounting and Finance, 50, 921-939.

SALAR (Swedish Association of Local Authorities and Regions) (2017). https://skl.se/demokratilednin gstyrning/revision/lekmannarevisionrevisionikommunalaforetag.1657.html (Accessed: August 25, 2017). 
Saldaña, J. (2009). The coding manual for qualitative researchers, Thousand Oaks. California: Sage Publications Inc.

Sands, V. (2006). The right to know and obligation to provide: Public-private partnerships, public knowledge, public accountability, public disenfranchisement and prison cases. UNSW Law Journal, 29(3), 334-341.

SCB [Statistics Sweden] (2014). Offentligt ägda företag 2014 [Publicly owned enterprises 2014]. Stockholm: SCB www.scb.se/Statistik/OE/OE0108/2014A01/OE0108_2014A01_SM_OE27SM1501. Pdf (Accessed: April 19, 2018).

Shaoul, J., Strafford, A., \& Stapleton, P. (2012). Accountability and corporate governance of public private partnerships. Critical Perspectives on Accounting, 23, 213-229.

Sherer, M., \& Turley, S. (Eds.). (1997). Current issues in auditing (3rd ed.). London: Paul Chapman.

Simunic, D. A. (1980). The pricing of audit services: Theory and evidence. Journal of Accounting Research, 18(1), 161-190.

Simunic, D. A., \& Stein, M. (1996). The impact of litigation risk on audit pricing: A review of the economics and the evidence. Auditing: A Journal of Practice and Theory, 15(2), 119-134.

Skinner, D., \& Srinivasan, S. (2012). Audit quality and auditor reputation: Evidence from Japan. The Accounting Review, 87(5), 1737-1765.

Stanley, J. D. (2011). Is the audit fee disclosure a leading indicator of clients' business risk? Auditing: A Journal of Practice and Theory, 30(3), 157-179.

Sundgren, S., \& Svanström, T. (2013). Audit office size, audit quality and audit pricing: evidence from small- and medium-sized enterprises. Accounting and Business Research, 43(1), 31-55.

Svanström, T. (2013). Non-audit services and audit quality: Evidence from private firms. European Accounting Review, 22(2), 337-366.

Tagesson, T., Glinatsi, N., \& Prahl, M. (2015). Procurement of audit services in the municipal sector: The impact of competition. Public Money \& Management, 35(4), 273-280.

Tagesson, T., \& Grossi, G. (2012). The materiality of consolidated reporting-An alternative approach to IPSASB. International Journal of Public Sector Performance Management, 2(1), 81-95.

The Swedish Companies Act 2005:551. available at https://www.riksdagen.se/sv/dokument-lagar/dokum ent/svensk-forfattningssamling/aktiebolagslag-2005551_sfs-2005-551(Accessed: December 6, 2017).

The Swedish Local Government Act 1991:900. available at http://www.government.se/49b736/contentass ets/9577b5121e2f4984ac65ef97ee79f012/the-swedish-local-government-act (Accessed: December 7, 2017).

Thinggaard, F., \& Kiertzner, L. (2008). Determinants of audit fees: Evidence from a small capital market with a joint audit requirement. International Journal of Auditing, 12(2), 141-158.

Thomasson, A. (2009a). Exploring the ambiguity of hybrid organisations: A stakeholder approach. Financial Accountability \& Management, 25(3), 353-366.

Thomasson, A. (2009b). Navigating in the landscape of ambiguity: A stakeholder approach to the governance and management of hybrid organizations. Lund: Lund University Press.

Viezer, T. W. (2000). Evaluating "within real estate" diversification strategies. Journal of Real Estate Portfolio Management, 6(1), 75-95.

Willekens, M., \& Achmadi, C. (2003). Pricing and supplier concentration in the private client segment on the audit market: Market power or concentration. International Journal of Accounting, 38(4), 431-455.

Zerni, M., Haapamäki, E., Järvinen, T., \& Niemi, L. (2012). Do joint audits improve audit quality? Evidence from voluntary joint audits. European Accounting Review, 21(4), 731-765.

Zimmerman, J. L. (1977). The municipal accounting maze: An analysis of political incentives. Journal of Accounting Research, 15, 107-144.

Linus Axén is a $\mathrm{PhD}$ candidate in accounting and auditing at Linköping University (Sweden).

Torbjörn Tagesson is Professor of Accounting at Linköping University (Sweden) and the Executive Director of the Swedish Council for Municipal Accounting. He received his Ph.D. in Business Administration from Lund University (Sweden) in 2002 and is the author of several books and articles on accounting, auditing, and public administration. 
Denis Shcherbinin holds a M.Sc. in Accounting and Auditing from Linköping University (Sweden). Azra Custovic holds a M.Sc. in Accounting and Auditing from Linköping University (Sweden). Anna Ojdanic holds a M.Sc. in Accounting and Auditing from Linköping University (Sweden). 